\title{
Semen Quality of Etawah Crossbreed Bucks Fed with Urea Moringa Molasses Multinutrient Block Supplemented with Native Grass Basal Feed
}

\author{
Nursyam Andi Syarifuddin*, Muhammad Rizal, Muhammad Riyadhi, and Anis
}

\author{
Wahdi
}

\author{
Department of Animal Science, Faculty of Agriculture, Lambung Mangkurat University \\ *Corresponding author.Email: nursyamas@ulm.ac.id
}

\begin{abstract}
Moringa leaves contain high and complete nutrients, so they can be used as a making block for multinutrient blocks to improve semen quality. This study aimed to evaluate the effect of using moringa leaf flour in a multinutrient block on the semen quality of Etawah crossbreed (EC) bucks fed by the native grass as basal feed. This study used eight heads of EC bucks aged $36.72 \pm 1.06$ months with a bodyweight of $54 \pm 2.97 \mathrm{~kg}$, which was kept intensively in individual cages for eight weeks. EC bucks were four heads to fed Urea Molasses Multinutrient Block (UMMB) supplement as a control, and four heads EC bucks were fed Urea Moringa Molasses Multinutrient Block (UMMMB) as a treatment. The EC bucks were fed the native grass ad libitum basis as the basal feed. Bodyweight and scrotal circumference measurements were carried out in the first, fourth, and eighth weeks to determine the performance of the experimental goats used. Semen collection for assessing the quality of fresh semen is carried out every week from week 4 to week 8 . The variables measured were compared using the independent sample t-test. UMMMB supplementation was not significant $(\mathrm{P}>0.05)$ decreased feed consumption ratio, increased body weight, and scrotal circumference $(3.10 \pm 0.02 \mathrm{vs} 2.99 \pm 0.09 \mathrm{kgDM}$; $0.12 \pm 0.01$ vs $0.14 \pm 0.04 \mathrm{~kg}$ /day; and $0.04 \pm 0.02$ vs $0.05 \pm 0.01 \mathrm{~cm})$. UMMMB supplementation did not significantly $(\mathrm{P}>0.05)$ improve the quality of fresh semen including volume, concentration, viability, abnormalities, and intact plasma membrane $\left(1.1 \pm 0.06\right.$ vs $1.1 \pm 0.05 \mathrm{ml} ; 389 \pm 25.43$ vs $419 \pm 11.49 \times 10^{7} ; 86.74 \pm 1.16$ vs. $88.66 \pm 1.30 \% ; 5.41 \pm 0.43$ vs. $5.61 \pm 0.64 \%$; and $87.00 \pm 1.11$ vs. $88.94 \pm 0.63$ ). Vice versa UMMMB supplementation significantly $(\mathrm{P}<0.05)$ increased the total motility of sperm the EC bucks $(76.72 \pm 1.16$ vs $80.26 \pm 0.61 \%)$. The Results of the present study demonstrated that UMMMB supplementation can improve the sperm quality of EC bucks.
\end{abstract}

Keywords: Semen quality, Etawah Cross-Breed, Moringa, Multinutrient block.

\section{INTRODUCTION}

The semen quality of a male was influenced by nutritional factors [1], age [2], breed [3], and season [4, 5]. Nutrition controls sperm production, gonadotropin secretion, and male sexual development [1]. One of the feedstuffs that contain high and complete nutrients that can be used to improve semen quality is Moringa oleifera leaves.

Moringa has the potential to be used as a feed ingredient because it has a high dry matter production. The results of the study by [6], in Managua, Nicaragua reached 15 tons/ha/year. The results of [7], research in the Mekong Delta, Vietnam reached 2.1 tons/ha/harvest (70 days) with a spacing of $40 \mathrm{~m} \times 30 \mathrm{~m}$. Meanwhile, the results of research by [8] in Taiwan reached 4.2-8.3 to/ha depending on fertilization, season, and ecological zone. The results of research by [9], in India reached 1.1-1.3 million tons/year, and the results of research by [10] in West Nusa Tenggara, Indonesia reached 8.7 tons/ha/harvest (120 days).

Moringa leaves contain high protein 30.29\% with 19 amino acids, six macro minerals, and six micro minerals. Moringa leaves contain 17 fatty acids, 11 of which are saturated fatty acids and three polyunsaturated fatty acids (PUFA), namely $\alpha$-linolenic, linoleic, and g-linolenic. Moringa leaves contain Vitamin A (Alpha and Betacarotene), B, B1, B2, B3, B5, B6, B12, C, D, E, K, folic acid, biotin, in abundance. Moringa leaves contain fiber 
fraction Neutral Detergent Fiber (NDF) 11.4\%, Acid Detergent Fiber (ADF) 8.49\%, Acid Detergent Lignin (ADL) $1.80 \%$, Acid Detergent Cellulose (ADC) $4.01 \%$ [11]. Moringa leaves contain low anti-nutritional substances in the form of tannin $21 \mathrm{~g} / \mathrm{kg}$ dry matter, pytat $21 \mathrm{~g} / \mathrm{kg}$ dry matter, and no trypsin and amylase inhibitors, lectins, cyanogenic glucosides, and glycosylates [12]. Moringa leaves also contain high strong antioxidants in the form of zeatin $(5-200 \mathrm{mcg} / \mathrm{g})$, quercetin, $\beta$ sitosterol, caffeoylquinic acid $(0.5-1 \%)$ and kaempferol [13], alkaloids, and $\gamma$-tocopherol, and xanthine [12].

Applied of moringa leaves as a feed ingredient has been shown to improve productivity and reproductivity in ruminants. Moringa leaf supplementation can increase bodyweight gain in goats by 78-86 g/day [14]. Moringa leaf supplementation up to $50 \%$ can increase gonadal and extragonadal sperm reserves, motility, and $\mathrm{pH}$ in Red Sakoto male goats [15]. Giving moringa leaves up to a level of $15 \%$ did not have a detrimental effect on testes morphometry and sperm quality of the male rabbit epididymis [16].

Moringa leaves are known to be used as feed ingredients to improve semen quality. Moringa leaves contain high levels of amino acids, methionine, and cysteine, which are important for the development of germ cells [17] as well as the amino acid arginine for spermatogenesis, precursors of putrescine, spermidine, and spermin synthesis important for sperm motility [18]. Moringa leaves contain PUFA which functions to maintain sperm cell viability, sperm maturation, and fertility [19;20]. Moringa leaves contain minerals $\mathrm{Zn}$ and Se which are important for the process of spermatogenesis [21]. $\mathrm{Zn}$ minerals at the beginning of spermatogenesis play a role in ribonuclease activity (Hidiroglou and Knipfel, 1984), during the spermatogenesis process it plays a role in spermatozoa maturation [22], maintains germinative epithelium and seminiferous tubules [23] and at the end of spermatogenesis plays a role in increasing sperm motility [22].

Mineral Se functions as a strong antioxidant combining with amino acids to form seleno-proteins and enzymes to form seleno-enzymes affecting sperm quality by preventing oxidative damage [21]. Moringa leaves contain vitamins $\mathrm{A}, \mathrm{C}$, and $\mathrm{E}$ which play an important role in the process of spermatogenesis [21].

The native grass has a low nutrient content. The results of [24] research on nine types of native grass obtained crude protein content between $3.48-7.60 \%$ and digestibility value $49.39-66.68 \%$. Farmers on ordinary people's farms use native grass as the main feed for their goats without feed supplements. The nutritional content of the feed will affect the quality of the semen produced, so that the buck is reared with native grass as the main feed need to be supplemented to improve the quality of their semen. Feeding multinutrient block supplements have been shown to improve the productivity and reproductivity of goats $[25,26]$. Supplementation with moringa mineral blocks has been shown to improve feed conversion (11.6 vs 18.3) and does not interfere with sheep health [27]. Multinutrient block moringa supplementation can increase crude protein intake 16.66 $\mathrm{g} /$ head/day) in Dwarf goats [28]. Therefore, this study tried to use moringa leaves as a making block for a multinutrient block supplement in the form of Urea Moringa Molasses Multinutrient Block (UMMMB) to improve the semen quality of EC bucks fed native grass as the main feed.

\section{MATERIAL AND METHODS}

\subsection{Animal, Experimental Design, and Diet}

This study used eight EC bucks, aged $36.72 \pm 1.06$ months, body weight $54 \pm 2.97 \mathrm{~kg}$ obtained from Breeding

Table 1. Compositions of the multinutrient block

\begin{tabular}{|c|l|c|c|}
\hline No & \multicolumn{1}{|c|}{ Feed Ingredients (\%) } & UMMB(Control) & UMMMB (Treatments) \\
\hline 1. & Moringa Leaf Flour & - & 30 \\
\hline 2. & Oil Palm meal & 25 & - \\
\hline 3. & Concentrate Laying Ducks (CP144 $\left.{ }^{\circledR}\right)$ & 5 & - \\
\hline 4. & Fine Rice Bran & 33 & 33 \\
\hline 5. & Molasses & 20 & 20 \\
\hline 6. & Lime & 5 & 5 \\
\hline 7. & Salt & 5 & 5 \\
\hline 8. & Urea & 5 & 5 \\
\hline 9. & Mineral Mix & 2 & 2 \\
\hline & Total & 100 & 100 \\
\hline
\end{tabular}


Table 2. Nutrient content of UMMB, UMMMB, and native grass (as \% DM).

\begin{tabular}{|c|l|c|c|c|}
\hline No & Nutrient composition (\%) & Native grass & UMMB & UMMMB \\
\hline 1. & Dry matter & 30.77 & 60.11 & 11.40 \\
\hline & Ash & 11.92 & 12.18 & 21.41 \\
\hline 3. & Crude Protein & 10.79 & 19.75 & 2.59 \\
\hline 4. & Crude Fiber & 31.52 & 3.11 & 2.51 \\
\hline 5. & Ether Extract & 0.62 & 2.82 & 3.78 \\
\hline 6. & Ca & 0.78 & 3.61 & 2.81 \\
\hline 7. & P & 0.44 & 2.05 & 62.09 \\
\hline 8. & Nitrogen Free Extract & 45.15 & 64.34 & 83.14 \\
\hline 9. & TDN & 55.38 & 83.44 & \\
\hline
\end{tabular}

Note: Analysed by Laboratory of Nutrition and Animal Feedstuff, Faculty of Agriculture, Animal Science Department, Lambung Mangkurat University

Centre Pelaihari. The goats were kept in individual cages $(1.25 \mathrm{~m} \times 1.00 \mathrm{~m})$. The EC bucks was fed by the native grass with ad libitum feeding as basal feed.

This study used the independent sample t-test to compare each observed variable. The EC bucks were divided into two groups. Four heads of EC bucks were fed UMMB supplement weighing 200g as a control and four heads ware fed by UMMMB supplement weighing $200 \mathrm{~g}$ as a treatment. The EC bucks kept for eight weeks were given rations according to the nutritional requirements for goats [29]. Supplementary feed was given in the morning before forage feeding. The composition of feed supplements for UMMB and UMMMB are presented in Table 1. The nutritional content of UMMB, UMMMB, and native grass used are presented in Table 2.

Bodyweight and scrotal circumference measurements were carried out at weeks 0,4 , and 8 to observe the to weight gain and scrotal circumference growth. Measurement of scrotal circumference using a measuring tailoring tape Butterfly ${ }^{\circledR}$ with a scale of $1 \mathrm{~mm}$ by wrapping the measuring tape tightly at the base of the scrotum, then slowly loosening it while lowering the scrotum downwards and the largest part of the scrotal circumference is the size of the scrotal circumference (cm). Semen quality measurements were carried out once a week for five weeks from the fourth to the eighth week. Semen collection was carried out at 07.00 - 10.00 AM before feeding. The collected semen was handled according to the fix procedures [30]. Semen was directly assessed macroscopically in the form of volume on a tube scale, followed by microscopic assessment of total motility, concentration, viability, and intact plasma membrane. Microscopic assessment using a Leica DM $300^{\circledR}$ microscope according to the procedure Susilawati [31].

\subsection{Statistical Analysis}

Data (performance production and semen quality) were reported as mean and standard error of mean analysed using the independent sample t-test with SPSS ${ }^{\circledR}$ Version 22 Sofware.

\section{RESULT AND ISCUSSION}

\subsection{Production Performance}

Table 3 shows that the rations consumption, average daily gain, ration efficiency, and increase in the scrotal circumference of EC bucks fed UMMMB supplement did not have a significant difference $(\mathrm{P}>0.05)$ with the control group.

Applied of moringa leaves in UMMMB supplement feed did not significantly reduce the dry matter consumption of the ration. According to [32], the dry matter consumption of animals is adjusted to the level of fatness (body composition) and/or the need for growth. The decrease in the consumption of dry matter rations, probably due to the complete nutritional content of moringa leaves, especially the high energy content of 329 calories per $100 \mathrm{~g}$ of dry leaves [33]. Applied of moringa leaves causes energy needs to be met, thereby reducing dry matter consumption. The average dry matter consumption in the control group was $3.10 \mathrm{~kg} /$ day while in the treatment group it was $2.99 \mathrm{~kg} / \mathrm{day}$. The average dry matter consumption is above the standard dry matter consumption requirement for male goats [29] which is $1.30 \mathrm{~kg} /$ day. 
Table 3. The performance production and increase the scrotal circumference of the EC buck in the control and treatment group.

\begin{tabular}{|c|c|c|c|}
\hline \multirow{2}{*}{ No } & \multirow{2}{*}{ Parameters } & UMMB (Control) & UMMMB (Treatment) \\
\hline & & \multicolumn{2}{|c|}{ (Means \pm SEM) } \\
\hline 1. & Ration consumption (kg DM) & $3.10 \pm 0.02$ & $2.99 \pm 0.09$ \\
\hline 2. & Average daily gain ( $\mathrm{kg} /$ day) & $0.12 \pm 0.01$ & $0.14 \pm 0.04$ \\
\hline 3. & Ration Efficiency & $0.04 \pm 0.00$ & $0.05 \pm 0.01$ \\
\hline 4. & Increased scrotal circumference $(\mathrm{cm})$ & $0.04 \pm 0.02$ & $0.05 \pm 0.01$ \\
\hline
\end{tabular}

Noted: Means in the same row with different superscripts differ significantly $(\mathrm{P}<0.05)$

Applied moringa leaves in UMMMB supplement feed did not significantly increase the bodyweight of EC bucks, because the dose of moringa leaves used is lower than that used for fattening. The main target in this study, not for body weight gain as in the study [14] using 20, 50, and $80 \%$ of moringa leaves from the total forage requirement, significantly increased body weight gain in Anglo-Nubian $\times$ Local Fiji goats. Therefore, in terms of ration efficiency, the utilization of moringa leaves in UMMMB supplementary feed was also inefficient compared to the control ( 0.05 vs 0.04$)$ although it did not show a significant difference. The smaller the ratio conversion value, the more efficient the livestock uses for feed.

The testes are the site of the formation of spermatozoa. The testes are covered by the scrotum which reflects the size of the testes and expresses the number of tissues or seminiferous tubules that function to produce spermatozoa. Applied of moringa leaves in UMMMB supplementary feed did not significantly increase scrotal circumference. It may be due to the age factor of the bucks used is three years old (36.72 \pm 1.06 months). According to [34], that the development of seminiferous tubules reaches the age of two years. Starting from the age of birth to the age of two years there is an increase in the number of Leydig cells which are regular with a perfect shape that has a cell nucleus and granular cytoplasm. Because the goat is more than two years old, the seminiferous tubules do not develop as they did when they were young. This condition is supported by the results of research by [35] on Savanah Brown buck, showing that the scrotal circumference is influenced by age. Scrotal circumference increases significantly between 12 and 18 months of age. Similarly, the results of [36] on Assam goats showed that the morphometry of seminiferous tubules and Leydig cells experienced a significant increase at the age of 6-8 months. Furthermore, according to [37] and [38] that the size of the scrotal circumference is influenced by body weight. This study used EC bucks whose body weight was relatively uniform $54 \pm 2.97 \mathrm{~kg}$, and body weight gain in this experimental goat also did not show a significant difference (Table 3) so that applied of moringa leaves in
UMMMB supplement feed did not show a significant difference.

\subsection{Semen Quality}

Table 4 shows that the volume, concentration, viability, abnormality, and intact plasma membrane (IPM) of the semen of EC bucks fed UMMMB supplement did not show significant differences $(\mathrm{P}>0.05)$ with the control group. The total motility of sperm EC bucks fed UMMMB supplement was significantly $(\mathrm{P}<0.05)$ higher than the control group. Applied of moringa leaves in UMMMB supplementary feed did not increase the semen volume of the PE bucks. The average semen volume of the bucks in the treatment and control groups was $1.1 \mathrm{ml}$. The semen volume did not show a difference was probably due to the low use of moringa leaves. The semen volume produced was included in the normal category.

The normal volume of goat semen according to [31] is $0.5-1.2 \mathrm{ml}$. The average semen volume obtained was the same as that obtained by [39] in PE goats, but higher than Bligon and Kejebong goats, respectively $0.87 \mathrm{ml}$, $0.54 \mathrm{ml}$, and $0.63 \mathrm{ml}$. The low average volume of semen in Bligon and Kejebong goats may be due to the influence of breed and body weight. The body weights of the male goats of Bligon and Kejebong goats used by [39] were $22.36 \pm 2.29 \mathrm{~kg}$ and $28.45 \pm 2.64 \mathrm{~kg}$, while in this study the weight was $54 \pm 2.97 \mathrm{~kg}$. According to [40], the volume of semen per ejaculate varies depending on the breed, age, body size, feed grade, and frequency of ejaculation. Similarly, according to [31] that the volume of ejaculated semen is influenced by the age of the male, physical condition, season, collector skills, and frequency of ejaculation.

Applied of moringa leaves in UMMMB supplement feed significantly $(\mathrm{P}<0.05)$ increased the total motility of sperm the EC bucks $(80.26 \%$ vs. $76.72 \%)$. The total motility is an indicator of semen quality assessment before freezing. According to [31], normal semen contains $70-90 \%$ motile spermatozoa. Based on [31], the total motility of sperm in the treatment and control groups, all of the accommodated semen was suitable for 
Table 4. The semen quality of the PE bucks in the control and treatment group.

\begin{tabular}{|c|c|c|c|}
\hline \multirow{2}{*}{ No } & \multirow{2}{*}{ Parameters } & UMMB (Control) & UMMMB (Treatment) \\
\hline & & \multicolumn{2}{|c|}{ (Means \pm SEM) } \\
\hline 1. & Volume (ml) & $1.1 \pm 0.06$ & $1.1 \pm 0.05$ \\
\hline 2. & Total motility (\%) & $76.72 \pm 1.16^{a}$ & $80.26 \pm 0.61^{\mathrm{b}}$ \\
\hline 3. & Concentration $\left(\times 10^{7}\right)$ & $389 \pm 25.43$ & $419 \pm 11.49$ \\
\hline 4. & Viability (\%) & $86.74 \pm 1.16$ & $88.66 \pm 1.30$ \\
\hline 5. & Abnormality (\%) & $5.41 \pm 0.43$ & $5.61 \pm 0.64$ \\
\hline 6. & Intact plasma membrane (\%) & $87.00 \pm 1.11$ & $88.94 \pm 0.63$ \\
\hline
\end{tabular}

Noted: Means in the same row with different superscripts differ significantly $(\mathrm{P}<0.05)$.

processing into liquid semen or frozen semen. The utilization of moringa leaves in UMMMB can increased the total motility of sperm the EC bucks. It is suspected that the mineral $\mathrm{Zn}$ contained in moringa leaves plays a role in increasing the total motility of sperm EC bucks.

The results of this study are in line with the research of [41] in crossbred bulls (Bos indicus $\times$ Bos taurus), organic and inorganic $\mathrm{Zn}$ supplementation significantly increased sperm motility. Similarly, the results of research by [42] on young Fries Holland bulls. The results of [43] also showed that $\mathrm{Zn}$ supplementation could significantly increase the motility of fresh and frozen sperm. This is supported by the statement of [44] that $\mathrm{Zn}$ supplementation causes an increase in the percentage of sperm motility. According to [45], that $\mathrm{Zn}$ minerals can increase the total motility of sperm because $\mathrm{Zn}$ minerals can provide movement energy for sperm so that they are more active. $\mathrm{Zn}$ mineral functions on the work of sperm cell metabolism enzymes to produce energy (adenosine triphosphate/ATP). Furthermore, [41] explained that, the increase in sperm motility because the main donor of energy needed by sperm flagella to move is ATP and Zn controls sperm motility by controlling energy utilization through the ATP system, through regulation of energy reserve phospholipids and increased absorption oxygen by sperm. Another reason is the activity of Zn-containing enzymes namely sorbitol dehydrogenase and lactate dehydrogenase which play an important role in sperm motility. $\mathrm{Zn}$ is also a scavenger of oxygen free radicals and protects sperm from oxidative damage and lipid peroxidation by inhibiting phospholipase. Thus, the antioxidant action of $\mathrm{Zn}$ may be responsible for the increase in sperm motility in the treatment group.

Applied of moringa leaves in UMMMB supplement feed did not significantly increase the sperm concentration of PE bucks. This is probably due to the low use of moringa leaves to provide significant differences in the scrotal circumference. The testes are the site of the formation of spermatozoa. The testes are covered by the scrotum which reflects the size of the testes and expresses the number of tissues or seminiferous tubules that function to produce spermatozoa. The average sperm concentration of bucks in the treatment group was 4,190 million/ml, slightly higher than the control group, which was 3,890 million $/ \mathrm{ml}$. The sperm concentration obtained was included in the normal category, because the normal concentration of male goat sperm was 2,500-5,000 million $/ \mathrm{ml}$ [46]. The sperm concentration obtained was the same as the results obtained by [39] in PE goats of 3,756 million/ml, but higher than the results of research by [47] on Saanen goats of $2,978 \mathrm{million} / \mathrm{ml}$ and the results were lower than the results of research by [39] in Bligon and Kejebong goats at 4,625 million/ml and 5,832 million $/ \mathrm{ml}$, respectively. Spermatozoa concentration is influenced by several factors, including male sexual maturity, ejaculate volume, holding interval, feed quality, reproductive health, testicular size, age, season, and geographical differences [48].

Applied of moringa leaves in UMMMB supplement feed did not significantly increase the sperm viability of PE goats. The average sperm viability of PE bucks in the treatment group was $88.66 \%$, while in the control group it was $86.74 \%$ were semen that had good viability, because according to [48] good semen had a viability percentage above $50 \%$. The sperm viability in both groups showed a high sperm viability, maybe the nutritional consumption of bucks is met including dry matter requirements, above the standard requirements based on [29] during rearing. Another possibility is due to the technical factors of the pens and the supportive environment during the research so that bucks can ejaculate normally. Differences in the percentage of viabilities spermatozoa can be influenced by differences in evaluation methods, genetic, the environment in which livestock are kept and also due to technical factors in the pen [43]. The percentage of sperm viability was slightly higher in the treatment group, possibly moringa leaves contain high antioxidants that are useful for preventing free radical activity against spermatozoa cell membrane damage that affects the viability and fertility of spermatozoa, acting as an energy source to maintain spermatozoa motility $(44,45]$. 
Sperm abnormalities are physical abnormalities of spermatozoa that occur due to the process of formation of spermatozoa in the seminiferous tubules or due to the process of spermatozoa traveling through the tractus reproduction of the male. [48] has classified abnormalities into primary and secondary abnormalities. Primary abnormalities include a head that is too large (macrocephalic), a head that is too small (microcephalic), a short head that is wide, piriform; double head, double tail; midsection folded, bent, enlarged, piriform; or interlocked abaxially at the base of the head; and tail coiled, severed or split. Secondary abnormalities include severed tail, tailless head, folded midsection, presence of proximal or distal protoplasmic granules, and detached acrosome. Applied of moringa leaves in UMMMB supplementary feed did not significantly increase sperm abnormalities of PE bucks. Based on the classification of spermatozoa abnormalities by [48], the spermatozoa abnormalities obtained were mostly secondary abnormalities, namely the severed tail, head without tail and folded middle. The sperm abnormalities in both groups were low so that the quality was good and suitable for artificial insemination. According to [48], the number of abnormal spermatozoa suitable for artificial insemination is no more than $20 \%$. Furthermore, [46] stated that spermatozoa abnormalities in goat semen by $8-10 \%$ have no effect on fertility, but if the abnormality exceeds $25 \%$ of the total ejaculation it will affect fertility. Then [48] also stated that abnormalities of more than $20 \%$ indicate poor quality of spermatozoa. Sperm abnormalities can usually fertilize an egg, but usually will cause the death of the fetus before birth. Spermatozoa abnormalities in some livestock vary. Abnormalities of spermatozoa occur in addition to hereditary factors but are also influenced by other factors such as diseases which if it attacks the reproductive organs will cause disturbances in the growth and development of reproductive organs, especially the testes which will cause the production of spermatozoa in tubules seminiferous not take place perfectly. Based on this, the number of sperm abnormal obtained indicated that the experimental goats were in good health, good managed in good environmental temperature.

Applied of moringa leaves in UMMMB supplement feed did not significantly increase the sperm IPM of EC bucks. The average percentage of sperm IPM of EC bucks in the treatment group was $88.94 \%$, while in the control group it was $87.00 \%$. Semen produced by bucks in both groups met the requirements to be processed and utilized in the Artificial Insemination program, because according to [50] the percentage of intact plasma membrane of fresh semen less than $60 \%$ was categorized as infertile semen. Previous researchers reported that the average percentage of IPM of Garut sheep was $87.73 \%$ $[51,52]$, and $87.83 \%$ [53] .

The results of this study showed that the fresh semen produced in the form of volume and concentration was normal. The fresh semen produced also has a high percentage of total motility, a high percentage of viabilities, and a high percentage of the intact plasma membrane, and a low percentage of abnormalities. Therefore, the semen produced was suitable for further processing into liquid semen and frozen semen and then tested for fertility to female acceptors by artificial insemination.

\section{CONCLUSION}

Applied moringa leaf flour as a constituent of Urea Moringa Molasses Multinutrient Block (UMMMB) can maintain the normal volume of semen, increase concentration, viability, and intact plasma membrane of spermatozoa, reduce the number of abnormal spermatozoa, and significantly increase the total motility of spermatozoa in Etawah crossbreed bucks.

\section{ACKNOWLEDGMENT}

The authors would like to thank the Ministry of Education and Culture, Indonesia for supporting this research through Applied Research with Research Contract No. 113.2.06/UN.8.2/PP/2019 dated May 25, 2020. The author also expresses his deepest gratitude to the Rukun Jaya Makmur Farmers Group, Banjarbaru City, South Kalimantan for providing pens and its facilities for the research.

\section{REFERENCES}

[1] Martin, G. B., D. Blache, D.W. Miller, \& E.Vercoe. 2010. Interactions between nutrition and reproduction in the management of the mature male ruminant. Animal 4(7):1214-1226. DOI:10.1017/S1751731109991674.

[2] Bhakat, M., T.K. Mohanty, V. S. Raina, A.K. Gupta, H. M. Khan, R.K. Mahapatra, \& M. Sarkar. 2011. Effect of age and season on semen quality parameters in Sahiwal bulls. Trop Anim Health Prod 43:1161-1168. DOI: 10.1007/s11250-011-9817-1.

[3] Lemma, A. \& T. Shemsu. 2015. Effect of age and breed on semen quality and breeding soundness evaluation of preservice young bulls. J. Reprod.

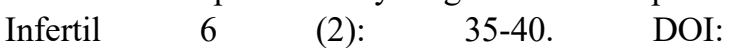
10.5829/idosi.jri.2015.6.2.94131.

[4] Elsheikh, A. S., \& N. S. Elhammali. 2015. Semen quality of mature crossbred male goatsduring different seasons. IOSR-JAVS 8(9) Ver. II, PP 0105. DOI: 10.9790/2380-08920105.

[5] Benia, A. R., M. A. Saadi, A. Ait-Amrane, T. B. Belhamiti, S. M. A. Selles \& R. Kaidi. 2018. Effect of season and age on main characteristics of sperm production in the Ouled-Djellal rams. Livestock 
Research for Rural Development. Volume 30, Article\#10.

http://www.lrrd.org/lrrd30/1/arbv30010.html.

[6] Sa'nchez, N. R., E. Spo“rndly, \& I. Ledin. 2005. Effect of Feeding Different Levels of Foliage of Moringa oleifera to Creole Dairy Cows on Intake, Digestibility, Milk Production and Composition. LIVSCI-02810; $\quad \begin{array}{llll}\text { No } & 1 & - & 8\end{array}$ doi:10.1016/j.livprodsci.2005.09.010.

[7] Manh, L. H., N. N. X. Dung and T. P. Ngoi. 2005. Introduction and evaluation of Moringa oleifera for biomass production and as feed for goats in the Mekong Delta. Livestock Research for Rural Development $17 \quad$ (9): 1 - 8: http://www.lrrd.org/lrrd17/9/manh17104.htm.

[8] Palada, M.C., L.C. Chang, R.Y. Yang \& L.M. Engle. 2007. Introduction and Varietal Screening of Drumstick Tree (Moringa spp.) for Horticultural Traits and Adaptation in Taiwan. Acta Hort 752: $249-253$

[9] Paliwal, R., V. Sharma \& Pracheta. 2011. A Review on Horse Radish Tree (Moringa oleifera): A Multipurpose Tree with High Economic and Commercial Importance. Asian Journal of Biotechnology 3 (4): 317 - 328. DOI: 10.3923/ajbkr.2011.317.328.

[10] Prisdiminggo, T. Panjaitan \& L.G.S. Astiti. 2013. Keragaan, Produksi dan Kualitas Kelor (Moringa oleifera L.) yang Ditanam dengan Biji di Kebun Balai Pengkajian Teknologi Pertanian Nusa Tenggara Barat. Abstrak Hasil Penelitian Pertanian Indonesia Volume 30, No. 2: 131. Kementerian Pertanian, Pusat Perpustakaan Dan Penyebaran Teknologi Pertanian.

[11] Moyo, B., P.J. Masika, A. Hugo \& V. Muchenje. 2011. Nutritional characterization of Moringa (Moringa oleifera Lam.) Leaves. African J. of Biotech 10(60):12925-12933. DOI: 10.5897/AJB10.1599.

[12] Ferreira, P. M. P., D.F. Farias, J.T. A. Oliveira \& A. F. U. Carvalho. 2008. Moringa oleifera: Bioactive Compounds and Nutritional Potential. Rev. Nutr., Campinas, 21(4) : 431-437.

[13] Anwar, F., S. Latif, M. Ashraf \& A. H. Gilani. 2007. Review Article Moringa oleifera: A Food Plant with Multiple Medicinal Uses. Phytother. Res. 21: 1725. DOI: $10.1002 /$ ptr.2023.

[14] Aregheore E.M. 2002. Intake and digestibility of Moringa oleifera-batiki grass mixtures for growing goats. Small Rum. Res. 46: 23-28.
[15] Raji, A.Y. \& A.A. Njidda. 2014. Gonadal and Extra-Gonodal Sperm Reserves of the Red Sokoto Goats Fed Moringa oleifera Supplemented Diets. Inter J Agri Biosci. Vol. 3 (2): 61-64.

[16]. Abu, A. H., T. Ahemen \& P. Ikpechukwu. 2013. The Testicular Morphometry and Sperm Quality Of Rabbit Bucks Fed Graded Levels of Moringa oleifera Leaf Meal (MOLM). Agrosearch 13 (1): 49 - 56. Http://dx.doi.org/10.4314/agrosh.v13i1.5.

[17].Ebisch, I.M., Peters, W.H., Thomas, C.M., Wetzels, A.M., Peer, P.G. \& Steegers-Theunissen, R.P. 2006. Homo-cysteine, glutathione and related thiols affect fertility pa-rameters in the (sub)fertile couple. Human Reproduction, 21, 1725-1733. DOI.org/10.1093/humrep/del081.

[18] Wu, G., Bazer, F.W., Davis, T.A., Kim, S.W., Li, P., Marc Rhoads, J., Satterfield, M.C., Smith, S.B., Spencer, T.E. \& Y. Yin. 2009. Arginine metabolism and nutrition in growth, health and disease. Amino Acids (37) : $153 \quad$ - 168. DOI:10.1196/annals.1320.017.

[19] Zalata, A.A., A. B Christophe, C. E. Depuydt, F. Schoonjans \& F.H. Comhaire. 1998 The fatty acid composition of phospholipids of spermatozoa from infertile patients. Molecular Human Reproduction (4): 111-118.

[20] Conquer, J.A., J. B. Martin, I. Tummon, L. Watson \& F. Tekpetey. 2000. Effect of DHA supplementation on DHA status and sperm motility in asthenozoospermic males. Lipids (35) : 149-154. DOI:10.1007/BF02664764.

[21] Cheah, Y \& W. Yang. 2011. Functions of essential nutrition for high quality spermatogenesis. Advances in Bioscience and Biotechnology (2): 182-197. DOI:10.4236/abb.2011.24029.

[22] Hidiroglou, M. \& J.E. Knipfel. 1984. Zinc in mammalian sperm: A review. Journal of Dairy Science (67): 1147 - 1156. DOI:10.3168/jds. S00220302(84)81416-2.

[23] Mason, K.E., W.A. Burns \& J.C. Smith Jr. 1982. Testicular damage associated with zinc deficiency in pre- and postpubertal rats: Response to zinc repletion. The Journal of Nutrition (112): 1019 1028.

[24] Wahyono, T., E. Jatmiko, Firsoni, S. N. W. Hardani, \& E. Yunita. 2019. Evaluasi Nutrien dan Kecernaan In Vitro Beberapa Spesies Rumput Lapangan Tropis di Indonesia. Sains Peternakan 17 (2):17-23. DOI: http://dx.doi.org/10.20961/sainspet.v\%vi\%i.29776.

[25] Faftine, O. L. J. \& A. M. Zanetti. 2010. Effect of multinutrient block on feed digestibility and 
performance of goats fed maize stover during the dry season in south of Mozambique. Livestock Research for Rural Development. Volume 22, Article \#162.

http://www.lrrd.org/lrrd22/9/faft22162.htm.

[26] Salman. A. D., K. M. El Shargi, R. S. Al-Habsi, \& T. Al-Sadairi. 2017. New development of feed blocks technology in the Sultanate of Oman. Livestock Research for Rural Development. Volume 29, Article \#109. http://www.lrrd.org/lrrd29/6/alaa29109.html.

[27] Adegun, M. K, , P.A. Aye, \& F. A. S. Dairo. 2011. Evaluation of Moringa oleifera, Gliricidia sepium and Leucaena leucocephala - based multinutrient blocks as feed supplements for sheep in South Western Nigeria. Agric. Biol. J. N. Am. Vol 2(11): 1395-1401.

DOI:10.5251/abjna.2011.2.11.1395.1401. (C) 2011, ScienceHuß, http://www.scihub.org/ABJNA

[28] Asaolu, V.O. \& A.T. Okewoye. 2013. Moringa multinutrient block supplementation effects on feed utilization by West African Dwarf goats fed a basal diet of cassava peels. Science Focus 18(1):63-72.

[29] National Reseacrh Council (NRC). 2007. Nutrient Requirement of Small Ruminant (Sheep, Goat, Cervids, and New World Camelids). The National Academies Press, Washington, D.C.

[30] Ax, R. L. M. Dally, B.A. Didion, R.W. Lenz, C.C. Love, D.D. Varner, B. Hafez and M.E. Bellin. 2000. Semen Evaluation. In : Reproduction in Farm Animals. Seventh edition. Lippincott Williams \& Wilkins. USA.

[31] Susilawati, T. 2011. Spermatologi. Universitas Brawijaya Press (UB Press), Malang (Indonesia).

[32] Parakkasi, A. 1999. Ilmu Nutrisi dan Makanan Ternak Ruminan. Universitas Indonesia Press (UI Press), Jakarta.

[33] Gopalakrishnan, L., K. Doriya, and D. S. Kumar. 2016. Moringa oleifera: A review on nutritive importance and its medicinal application. Food Science and Human Wellness 5:49-56. http://dx.DOI.org/10.1016/j.fshw.2016.04.001.

[34] Salisbury, G. W. \& N. L. VanDemark.1985. Alih Bahasa oleh R. Djanuar. Fisiologi Reproduksi dan Inseminasi Buatan Pada Sapi. Gadjah Mada University Press, Yogyakarta.

[35] Shoyombo, A., O. Fasanya, U. Bunjah \& H. Yakubu. 2012. On-farm prediction of testicular characteristics in bucks at specific ages. World $\mathrm{J}$ Life Sci. and Medical Research 2(3):114-7.
[36] Sarma, K. \& J. Devi. 2017. Morphometrical changes of the seminiferoustubules and Leydig cells in Assam goats (Capra hircus) from birth to 10 months. J. Appl. Anim. Res. 45(1): 268-274. DOI: https://doi.org/10.1080/09712119.2016.1174127.

[37] Sullivan, P.G. 1996. A multiple breed age adjustments for scrotal circumferences. Beef improvement. Ontario, Dept. of Animal and Poultry Science, University of Guelph.

[38] Tozser, J. M., Meezes \& L. Alfoldi. 1999. Comparative study for adjusting scrotal circumferences in charolais and Hungarian Simmental young bulls. Pannon University of Agriculture Faculty of Animal Science, Kapovar.

[39] Rachmawati, L., Ismaya, \& P. Astuti. 2014. Korelasi antara hormon testosteron, libido, dan kualitas sperma pada kambing bligon, kejobong, dan peranakan etawah. Buletin Peternakan Vol. 38(1): 8-15.

[40] Feradis. 2010. Bioteknologi Reproduksi Pada Ternak. Alfabeta. Bandung.

[41] Kumar, N., R. P. Verma, L. P. Singh, V. P. Varshney, \& R. S. Dass. 2006. Effect of different levels and sources of zinc supplementation on quantitative and qualitative semen attributes and serum testosterone level in crossbred cattle (Bos indicus $\times$ Bos taurus) bulls. Reprod Nutr Dev 46:663-675. DOI:10.1051/ rnd:2006041.

[42] Widhyari, S. D., A. Esfandiari, A. Wijaya, R. Wulansari, S. Widodo, \& L. Maylina. 2015. Tinjauan penambahan mineral $\mathrm{Zn}$ dalam pakan terhadap kualitas spermatozoa pada sapi Frisian Holstein jantan. Jurnal Ilmu Pertanian Indonesia (JIPI). Vol. 20 (1): $72-77$.

[43] Dethan, A.A., Kustono, \& H. Hartadi. 2010. Kualitas dan kuantitas sperma kambing bligon jantan yang diberi pakan rumput gajah dengan suplementasi tepung darah. Buletin Peternakan 34(3):145-153.

[44] Lubis, T.M., Dasrul, C.N. Thasmi, \& T. Akbar. 2013. Efektivitas penambahan vitamin $\mathrm{C}$ dalam pengencer susu skim, kuning telur terhadap kualitas spermatozoa kambing Boer setelah penyimpanan dingin. Jurnal S. Pertanian 3(1): 347-361.

[45] Aslam, H.A., Dasrul \& Rosmaidar. 2014. Pengaruh penambahan vitamin $\mathrm{C}$ dalam pengencer Andromed terhadap persentase motilitas dan membran plasma utuh spermatozoa sapi Aceh setelah pembekuan. Jurnal Medika Veterinaria 8(1): 20-26. 
[46] Hafez, E .S. E. 2000. Preservation and cryopreservation of gametes and embryos. In: Reproduction in Farm Animals. 7th ed. E. S. E. Hafez and B. Hafez (eds). Lippincot Williams \& Wilkins, Philadelphia.

[47] Tambing, S. N., M. R. Toelihiere, T. L. Yusuf), B. Purwantara, K. Sutama, \& P. Z. Situmorang. 2003. Pengaruh frekuensi ejakulasi terhadap karakteristik semen segar dan kemampuan libido kambing Saanen. Jurnal Sain Veteriner 21(2):57-65. https://doi.org/10.22146/jsv.504.

[48] Toelihere, M.R. 1993. Inseminasi Buatan pada Ternak. Angkasa, Bandung.

[49] Partodihardjo S. 1992. Ilmu Reproduksi Hewan. Penerbit Mutiara, Jakarta.

[50] Revell, S.G., \& R. A. Mrode. 1994. An osmoticresistance test for bovine semen. Anim Reprod Sci 36:77-86.

[51] Rizal, M., M. R. Toelihere, T. L. Yusuf, B. Purwantara, \& P. Situmorang. 2003. Karakteristik penampilan reproduksi pejantan domba garut. J Ilmu Ternak dan Veteriner 8:134-140.

[52] Herdis. 2005. Optimalisasi Inseminasi Buatan Melalui Aplikasi Teknologi Laserpunktur pada Domba Garut (Ovis aries). Disertasi. Bogor: Institut Pertanian Bogor.

[53] Rizal, M, Herdis, \& I. Sangadji. 2013. Fetal Bovine Serum dalam pengencer tris mempertahankan kehidupan dan keutuhan membran plasma spermatozoa semen beku domba garut. Jurnal Veteriner. 14(4): 437 - 443. 